\section{Production Environment and Nitrogen Fertility Affect Carrot Cracking}

\author{
T.K. Hartz, P.R. Johnstone, and J.J. Nunez ${ }^{1}$ \\ Department of Vegetable Crops, University of California, Davis, CA 95616
}

Additional index words. Daucus carota, irrigation, soil, temperature, water potential, turgor, periderm

\begin{abstract}
Carrot (Daucus carota L.) root cracking and breakage during harvest and handling operations result in serious losses. The environmental and management factors affecting carrot cracking and breakage susceptibility were investigated in a survey of fields and a series of trials conducted in California from 2000-02. Roots, leaves and soil were collected from a total of 31 commercial fields of 'Sugar Snax' carrot, and soil texture and plant and soil fertility status were determined. Soil moisture was monitored in 10 fields to determine whether irrigation management was correlated with root cracking susceptibility; in 4 of these fields roots were harvested both before $0800 \mathrm{HR}$ and at $1300 \mathrm{HR}$ on the same day to directly compare the effects of root water status on cracking. The effect of $\mathbf{N}$ fertilization on cracking and breakage was investigated in $\mathbf{5}$ field trials. The relative susceptibility of $\mathbf{1 0}$ cultivars to cracking and breakage was also compared. Cracking susceptibility was determined with an impact test, and breakage with a loading test. Roots were selected by size (18 to $24 \mathrm{~mm}$ diameter) and cooled to $5^{\circ} \mathrm{C}$ before testing. The percentage of roots cracked in the impact test varied from $7 \%$ to $75 \%$ among survey fields. Initial root water potential was not correlated with cracking incidence. However, after hydrating roots to minimize differences in water potential among fields, cracking incidence was correlated with turgor potential $(r=0.41)$. Soil sand content and mean air temperature in the 30 days preceding harvest were also correlated with cracking $(r=-0.48$ and 0.36 , respectively), suggesting that cracking susceptibility may be minimized in cool weather and in light-textured soil. Irrigation management in the final $\mathbf{3 0}$ days preceding harvest had no consistent effect on root cracking. Time of day of harvest had a small but significant effect, with roots harvested before 0800 HR being more crack-susceptible. $\mathrm{N}$ fertilization in excess of that required to maximize root yield significantly increased cracking susceptibility. Cultivars varied widely in cracking susceptibility, with less variation in tissue strength and stiffness. Removal of the periderm dramatically decreased susceptibility to both cracking and breakage.
\end{abstract}

Longitudinal cracking and transverse breakage of carrot roots result in significant losses to commercial growers worldwide. In California, root cracking is a particularly significant problem for carrots grown for cutand-peel processing for fresh market. While it has been widely demonstrated that cultivars differ significantly in susceptibility to cracking and breakage (Cantwell et al., 1991; Hole et al., 1999; McGarry, 1993; Sorenson, 1997), cultivars possessing the requisite textural qualities for cut-and-peel use tend to be highly cracking-sensitive. Furthermore, for a given cultivar, the degree of cracking and breakage encountered varies widely among production fields. Identification of the factors governing cracking sensitivity may allow the development of field production, harvesting and handling practices that minimize root damage.

Physiological studies on carrot cracking have produced contradictory results. McGarry (1993, 1995) reported that failure force of parenchyma tissue was negatively correlated with both water potential and turgor potential. Similarly, Golacki (1993) found that resistance to impact loading increased as root water potential decreased. However, difference in cracking

Received for publication 11 May 2004. Accepted for publication 11 Sept. 2004.

${ }^{1}$ University of California Cooperative Extension, Kern County. sensitivity among cultivars was unrelated to differences in water status (McGarry, 1993; Sorensen, 1997). Furthermore, Hole et al. (1999) found no consistent relationship between root cracking susceptibility and water status, either within or between cultivars. Agronomic and environmental factors have also been studied. Heavy N sidedressing (Bienz, 1965) and excessive soil drying between irrigations (Nortje and Henrico, 1986) increased cracking incidence. Increasing plant population reduced cracking (Bienz, 1965), probably by reducing mean carrot size; damage susceptibility increased as root size increased (Cantwell et al., 1991; Hole et al., 1999). Root temperature (Cantwell et al., 1991; Kokkoras, 1995) also has significant influence on carrot cracking or breaking. The objective of the present study was to investigate the influence of cultivar, field environment, soil fertility, and irrigation management on root cracking and breakage susceptibility during carrot harvest and handling.

\section{Materials and Methods}

Field survey. Several hundred roots plus 15 to 20 whole plants were hand harvested from each of 26 commercial fields of 'Sugar Snax' carrot in the Imperial and San Joaquin Valleys of California over the period 2000-02. These fields represented all seasons and a wide range of soil and environmental conditions.
Composite samples of leaves and soil (top $0.3 \mathrm{~m}$ ) were also collected. The roots and intact plants were placed in plastic bags to minimize water loss and transported on ice to the University of California, Davis (UCD), where they were cooled overnight at $5{ }^{\circ} \mathrm{C}$. The following day the water potential of the roots was estimated by pressure chamber (model610, PMS Instruments, Corvallis, Ore.) analysis of leaves excised from five different intact plants; moisture equilibrium between roots and leaves would be expected after the minimum of $12 \mathrm{~h}$ in the plastic bags (Fulton et al., 2001). Undamaged roots were then selected for cracking susceptibility testing.

Root water potential varied considerably among fields, so to more clearly distinguish the effects of root water status an attempt was made to standardize the water potential of roots from 18 of the fields. Detached roots, and the roots of intact plants, were immersed in water at 5 ${ }^{\circ} \mathrm{C}$ until leaf water potential averaged between -0.3 and $-0.1 \mathrm{MPa}$. These hydrated roots were then subjected to crack testing.

Leaf and whole root samples from all fields were oven-dried at $65{ }^{\circ} \mathrm{C}$, then ground. $\mathrm{N}$ concentration was quantified by a combustion technique (Pella, 1990), P, K, Ca, Mg, Na, and $\mathrm{B}$ by plasma-atomic emission spectrometry (Meyer and Keliher, 1992) following microwave acid digestion (Sah and Miller, 1992). The soil was air-dried and sieved to pass a $2-\mathrm{mm}$ screen. Particle size analysis was performed by the method of Gee and Bauder (1982). Bicarbonate extractable $\mathrm{P}$ (Olsen and Sommers, 1982) and ammonium acetate exchangeable cations (K, Ca, Mg, and $\mathrm{Na}$, Thomas, 1982) were determined. Soil $\mathrm{pH}$ was determined on saturated paste extracts, and organic matter content was estimated by the Walkey-Black method (Nelson and Sommers, 1982).

Effect of $N$ fertility. The effect of $\mathrm{N}$ fertility on carrot cracking sensitivity was investigated in five sprinkler-irrigated commercial fields of 'Sugar Snax' carrot. All trials were located in Kern County, California, in fields with $<10$ $\mathrm{g} \cdot \mathrm{kg}^{-1}$ organic matter. In each field three $8 \times 8$ $\mathrm{m}$ plots received $\mathrm{N}$ fertilizer application in addition to that applied by the cooperating grower. Yield of roots and leaves, plant $\mathrm{N}$ status, and root cracking sensitivity of these plots were compared to matching plots receiving only the growers' $\mathrm{N}$ application. The experimental design was a randomized block. The additional $\mathrm{N}$, in urea form, was broadcast in one or two applications made 4 to 8 weeks preharvest. Cultural details are given in Table 1. Plants were hand-harvested from four randomly selected $1.0 \times 1.0 \mathrm{~m}$ sections per plot and the mass of leaves and roots determined. Roots were bagged in plastic, transported to UCD, and cooled overnight at $5{ }^{\circ} \mathrm{C}$ before testing. Samples of both leaves and roots were ovendried, ground, and analyzed for $\mathrm{N}$ concentration by the combustion method.

Effect of water status. To determine whether irrigation management over the final month of the season (the period during which the majority of root biomass developed) affected root cracking susceptibility, soil moisture tension was monitored in the grower $\mathrm{N}$ treatment of 


\begin{tabular}{|c|c|c|c|c|c|c|}
\hline \multirow[b]{2}{*}{ Site } & \multirow[b]{2}{*}{ Soil } & \multirow[b]{2}{*}{ Soil classification } & \multirow[b]{2}{*}{ Soil pH } & \multirow[b]{2}{*}{ Harvest date } & \multicolumn{2}{|c|}{ Seasonal $\mathrm{N}$ rate $\left(\mathrm{kg} \cdot \mathrm{ha}^{-1}\right)$} \\
\hline & & & & & Grower & Grower + urea \\
\hline 2 & Cerini sandy loam & Fine-loamy, mixed (calcareous), thermic Typic Torrifluents & 7.4 & 20 June 2000 & 137 & 249 \\
\hline 4 & Panoche loam & Fine-loamy, mixed (calcareous), thermic Typic Torriorthents & 7.0 & 19 June 2002 & $59^{z}$ & 149 \\
\hline $5^{\mathrm{y}}$ & Wasco sandy loam & Coarse-loamy, mixed, nonacid, thermic Typic Torriorthents & 6.5 & 3 Dec. 2002 & $109^{z}$ & 243 \\
\hline
\end{tabular}

${ }^{\mathrm{z}} 4$ to $8 \mathrm{Mg} \cdot \mathrm{ha}^{-1}$ composted dairy manure also applied in these fields.

y Cultivar trial site.

the $\mathrm{N}$ trials and in four survey fields. All fields were sprinkler-irrigated. Resistance sensors (Watermark blocks, Irrometer Co., Riverside, Calif.) were installed 20 and $40 \mathrm{~cm}$ deep in plant rows, three replicate sensors per depth. Resistance readings were recorded every $6 \mathrm{~h}$ by datalogger (model 21X; Campbell Scientific, Logan, Utah) and converted to MPa tension by the method of Thompson and Armstrong (1987).

In four of these fields the effect of root water potential on cracking susceptibility was further investigated by harvesting roots in the early morning, and at midday. The evening before harvest individual leaves were enclosed in aluminized plastic bags to prevent transpiration, and allow the leaves to establish moisture equilibrium with the roots (Fulton et al., 2001). The following morning samples of roots from three areas of the field were harvested and bagged before $0800 \mathrm{HR}$; concurrently, half of the bagged leaves were removed from the plants and their water potential determined by pressure chamber analysis. An additional set of root samples were harvested at $1300 \mathrm{HR}$, at which time the water potential of the remaining bagged leaves was determined. All root samples were transported to UCD and cooled overnight at $5{ }^{\circ} \mathrm{C}$ before testing.

Comparison of cultivars. Susceptibility to cracking and breakage of 10 commercial carrot cultivars was compared in a commercial field trial conducted near Bakersfield, Calif., in 2002. The cultivars selected had all been evaluated by the California industry and were considered to have suitable characteristics for the cut-and-peel market. The trial was planted $8 \mathrm{Aug}$. in a field of Wasco sandy loam (coarse-loamy, mixed, nonacid thermic Typic Torriorthent, site 5, Table 1). To determine the effect of $\mathrm{N}$ fertility, cultivar response to two levels of $\mathrm{N}$ fertilization was compared. The $\mathrm{N}$ regimes were the grower's $\mathrm{N}$ application (a seasonal total of $109 \mathrm{~kg} \cdot \mathrm{ha}^{-1} \mathrm{~N}$ ) and the grower program plus two applications of urea at 67 $\mathrm{kg} \cdot \mathrm{ha}^{-1} \mathrm{~N}$ each, applied 17 Sept. and 24 Oct. The experimental design was a split plot within a randomized complete block; $\mathrm{N}$ rate was the main plot, cultivar the split plot. Individual cultivar plots were one $1 \mathrm{~m}$ bed wide by $12 \mathrm{~m}$ long. Roots were hand harvested on 3 Dec., transported in plastic bags to UCD, and cooled overnight at $5^{\circ} \mathrm{C}$.

Cracking and breakage evaluation. To minimize the effects of carrot size (Cantwell et al., 1991; Hole et al., 1999) and temperature (Cantwell et al., 1991; Kokkoras, 1995) all measurements of susceptibility to cracking and breakage were conducted on roots with a crown diameter of 18-24 $\mathrm{mm}$ that had been cooled to $5^{\circ} \mathrm{C}$. An impact test was used to determine root cracking susceptibility. Undamaged roots (no cracks or breaks) from the survey fields, $\mathrm{N}$ trials, and time of day comparisons were dropped from a height of $0.75 \mathrm{~m}$ onto an aluminum plate angled $30^{\circ}$ from the horizontal. Roots from the cultivar evaluation were dropped from $1.0 \mathrm{~m}$ height to ensure some degree of cracking in all cultivars. The roots were dropped through a tube to ensure that the crown consistently struck the plate at the same angle (Cantwell et al., 1991). The percentage of roots cracked by the impact was recorded. Additionally, a cracking index was calculated to quantify the severity of the cracks developed. The index was calculated by the formula:

$[($ no. roots with cracks $>5 \mathrm{~cm} \times 2)+($ no. roots with cracks $<5 \mathrm{~cm})] /$ no. roots tested [1]

In cut-and-peel processing carrots are cut into about $5 \mathrm{~cm}$ segments, so cracks $>5 \mathrm{~cm}$ would affect multiple segments. The cracking index, by weighting large cracks, provided a more accurate measure of economic loss than the percentage of cracked roots. Sixty roots per survey field were tested. For the $\mathrm{N}$ rate trials 30 roots per $\mathrm{N}$ treatment per block were tested, and 30 roots per cultivar per $\mathrm{N}$ treatment per block were tested in the cultivar evaluation.

Cores of phloem parenchyma were excised from nine roots per field (survey fields) or three roots per treatment per block ( $\mathrm{N}$ trials and cultivar evaluation) and frozen with liquid nitrogen. After thawing at room temperature these cores were crushed and the osmotic potential of the expressed sap measured by a vapor pressure osmometer (model 5100; Wescor Inc., Logan, Utah). Root turgor potential was calculated as water potential minus osmotic potential.

For the cultivar evaluation and the $\mathrm{N}$ trials conducted in 2002, the force required to cause transverse breakage of roots, and the deformation distance before breakage, was determined using a texture analyzer (model TA-XT2i; Texture Technologies Corp., Scarsdale, N.Y.). Carrots were placed on two support posts 65 $\mathrm{mm}$ apart. A blunt wedge was driven into the suspended root at a constant speed of $5 \mathrm{~mm} \cdot \mathrm{s}^{-1}$ until breakage, with resistance force and deformation distance continuously recorded. Ten roots per $\mathrm{N}$ rate or cultivar per block were tested. From these data tensile stress at the point of failure (a measure of tissue strength) and modulus of elasticity (a measure of tissue stiffness) were calculated by the following formulae (adapted from Mohsenin, 1986): Tensile stress $\left.=(\mathrm{F} \cdot \mathrm{L}) / \pi \cdot \mathrm{r}^{3} / 2\right)$ and

modulus of elasticity $=\left(F \cdot L^{3}\right) /\left(48 \mathrm{D} \cdot \pi \cdot r^{4} / 4\right)[3]$ where $\mathrm{F}=$ force $(\mathrm{N})$ at failure, $\mathrm{L}=$ length $(\mathrm{mm})$ between support posts, $\mathrm{D}=$ deformation $(\mathrm{mm})$ before failure, $r=$ radius $(\mathrm{mm})$ of the carrot at the point of failure.

To document the influence of the periderm on cracking and breakage, roots from the 2002 $\mathrm{N}$ trials and the cultivar evaluation were peeled and subjected to both the impact and breakage tests. Fifteen roots per $\mathrm{N}$ treatment or cultivar per block were evaluated on the impact test. Only roots from the grower $\mathrm{N}$ plots were evaluated on the breakage test. Ten roots per subplot were tested.

\section{Results}

Across locations, $\mathrm{N}$ application in excess of that applied by the growers increased leaf biomass but did not increase root yield (Table 2). Excess $\mathrm{N}$ fertilization increased the root cracking percentage from $39 \%$ to $50 \%$, and cracking index from 0.50 to 0.69 . Cracking percentage of roots receiving the growers' $\mathrm{N}$ regime varied among sites from $30 \%$ to $56 \%$. Root strength and stiffness were unaffected by $\mathrm{N}$ treatment. Periderm removal by peeling had profound effects. Cracking was dramatically reduced. Across sites, tensile stress at failure was significantly increased by peeling. Peeled roots deformed nearly twice as far before breaking as roots with intact periderm, thereby reducing modulus of elasticity despite increased carrot strength.

In the cultivar evaluation the application of additional $\mathrm{N}$ increased cracking incidence across cultivars from $35 \%$ to $46 \%$, and crack index from 0.44 to 0.61 (data not shown); there was no $\mathrm{N} \times$ cultivar interaction. At all trial locations the grower $\mathrm{N}$ application rate was conservative (59 to $137 \mathrm{~kg} \cdot \mathrm{ha}^{-1} \mathrm{~N}$, Table 1). Fertilization records obtained for 10 of the survey fields showed that mean seasonal $\mathrm{N}$ rate exceeded $190 \mathrm{~kg} \cdot \mathrm{ha}^{-1}$, suggesting that the additional $\mathrm{N}$ treatment in the $\mathrm{N}$ trials represented seasonal $\mathrm{N}$ rates similar to that used in many commercial fields.

Cultivars varied in cracking susceptibility, ranging from $14 \%$ to $53 \%$ of roots cracked in the impact test (Table 3); the crack index ranged from 0.15 to 0.76 . Cultivars also varied in root strength and stiffness, but there was no correlation between either of those measures and cracking susceptibility. Periderm removal virtually eliminated cracking. Peeled roots had both increased tissue strength, and increased flexibility. Across cultivars, there was no correlation between tissue strength or stiffness of intact roots and that of peeled roots.

Irrigation management over the final $30 \mathrm{~d}$ before harvest varied widely among the fields monitored, but had no consistent effect on 


\begin{tabular}{|c|c|c|c|c|c|c|c|c|c|c|c|c|}
\hline \multirow[b]{2}{*}{ Year } & \multirow[b]{2}{*}{ Site } & \multirow{2}{*}{$\begin{array}{l}\mathrm{N} \\
\text { treatment }\end{array}$} & \multicolumn{2}{|c|}{$\begin{array}{l}\text { Fresh wt } \\
\left(\mathrm{Mg} \cdot \mathrm{ha}^{-1}\right)\end{array}$} & \multicolumn{2}{|c|}{$\begin{array}{l}\text { Percent } \\
\text { cracked }\end{array}$} & \multicolumn{2}{|c|}{$\begin{array}{l}\text { Crack } \\
\text { index }\end{array}$} & \multicolumn{2}{|c|}{$\begin{array}{c}\text { Tensile stress } \\
\text { at failure } \\
\left(\mathrm{N} \cdot \mathrm{mm}^{-2}\right)\end{array}$} & \multicolumn{2}{|c|}{$\begin{array}{l}\text { Modulus of } \\
\text { elasticity } \\
\left(\mathrm{N} \cdot \mathrm{mm}^{-2}\right)\end{array}$} \\
\hline & & & Leaves & Roots & Intact & Peeled & Intact & $\overline{\text { Peeled }}$ & Intact & $\overline{\text { Peeled }}$ & Intact & Peeled \\
\hline \multirow[t]{2}{*}{2000} & 2 & Grower N & 8.7 & 49.3 & 37 & & 0.40 & & & & & \\
\hline & & Additional N & 10.6 & 53.0 & 40 & & 0.55 & & & & & \\
\hline 2002 & 3 & Grower N & 10.4 & 40.7 & 30 & 7 & 0.37 & 0.07 & 3.07 & 3.75 & 4.59 & 3.01 \\
\hline 2002 & & Additional N & 8.4 & 37.0 & 74 & 0 & 1.09 & 0.00 & 2.99 & & 4.90 & \\
\hline \multirow[t]{2}{*}{2002} & 5 & Grower N & 8.0 & 34.5 & 39 & 2 & 0.44 & 0.02 & 3.84 & 5.22 & 5.38 & 4.42 \\
\hline & & Additional $\mathrm{N}$ & 9.7 & 33.5 & 61 & 2 & 0.72 & 0.02 & 3.84 & & 5.16 & \\
\hline \multirow[t]{3}{*}{ Mean } & & Grower N & 10.0 & 45.0 & $39 b^{2}$ & $5 \mathrm{a}$ & $0.50 \mathrm{~b}$ & $0.06 \mathrm{a}$ & $3.35 \mathrm{a}$ & $4.42 \mathrm{~b}$ & $4.96 \mathrm{~b}$ & $3.77 \mathrm{a}$ \\
\hline & & Additional N & 11.3 & 45.0 & 50 & 3 & 0.69 & 0.03 & 3.26 & & 4.83 & \\
\hline & & & 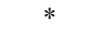 & NS & * & NS & ** & NS & NS & & NS & \\
\hline
\end{tabular}

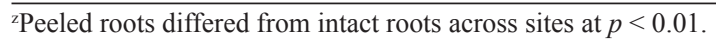

NS,*,**N Nonsignificant or significant differences for grower $\mathrm{N}$ and additional $\mathrm{N}$ treatments across sites at $p<0.05$ or 0.01 , respectively.

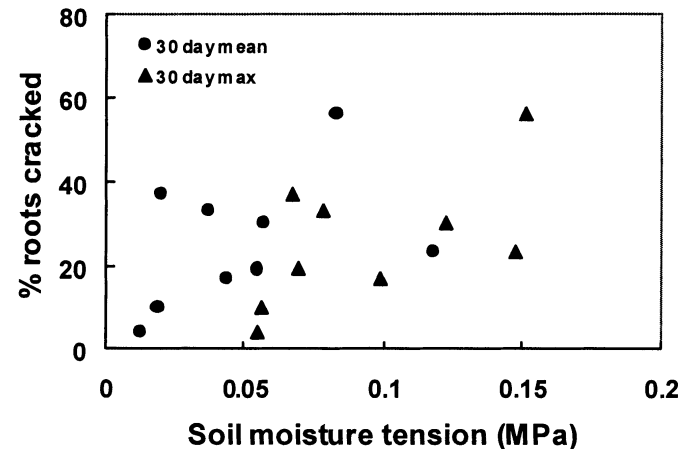

Fig. 1. Root cracking susceptibility among fields as affected by soil moisture tension (top $0.4 \mathrm{~m}$ depth) over the final $30 \mathrm{~d}$ of growth.
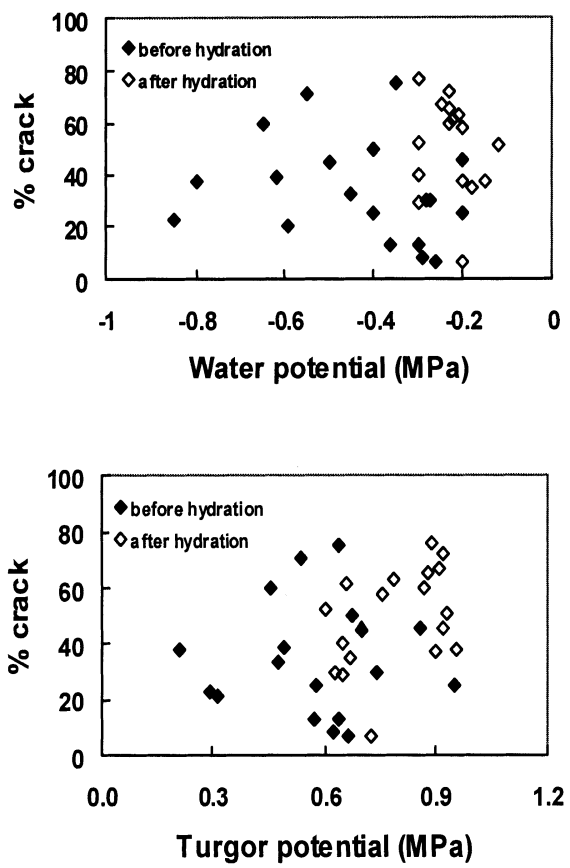

Fig. 2. Cracking susceptibility among fields, as affected by root water status; hydration refers to water soaking treatment to standardize root water potential among fields.

cracking susceptibility (Fig. 1). Neither the mean nor the maximum soil moisture tension was correlated with cracking incidence. Time of day of harvest had a small but significant effect on root cracking susceptibility; across the four fields evaluated, roots harvested before $0800 \mathrm{HR}$ averaged $23 \%$ cracking on the impact test, compared to $18 \%$ for roots harvested at $1300 \mathrm{HR}$. Root water potential averaged $0.3 \mathrm{MPa}$ lower at 1300 than at $0800 \mathrm{HR}$.

Root cracking varied among the survey fields from $7 \%$ to $75 \%$, but was not correlated with water potential (Fig. 0.2 2). Following hydration to bring root water potential among fields within a narrow range $(-0.1$ to $-0.3 \mathrm{MPa})$, cracking was correlated with turgor potential $[\%$ cracked $=3+(58 \times$ MPa turgor $), r=0.41]$. Hydration increased cracking significantly, but fields still varied in cracking incidence from $7 \%$ to $76 \%$.

Combined data from the survey fields and the $\mathrm{N}$ trials (grower $\mathrm{N}$ treatment only) showed that no measure of nutrient status of leaves or roots at harvest was correlated with root cracking susceptibility (data not shown), but several soil and environmental variables were (Table 4). Air temperature over the final $30 \mathrm{~d}$ of growth was positively correlated with cracking. The 10 fields with the highest incidence of root cracking all had mean temperature $>17^{\circ} \mathrm{C}$, while 8 of the 10 fields with the lowest incidence had mean temperature below that level. Soil pH was not correlated with cracking susceptibility, but soil texture was; the heavier the texture, the greater the cracking susceptibility. The 10 fields with the greatest sand content averaged only $27 \%$ cracking while the 10 fields with the lowest sand content averaged $42 \%$. The correlation observed between cracking incidence and soil $\mathrm{Ca}$ and $\mathrm{Mg}$ was assumed to be an artifact of the close association of exchangeable $\mathrm{Ca}$ and $\mathrm{Mg}$ to soil texture; the correlation of percent sand to soil exchangeable $\mathrm{Ca}$ and $\mathrm{Mg}$ was -0.87 and -0.71 , respectively. Neither leaf nor whole root $\mathrm{Ca}$ or $\mathrm{Mg}$ status was not correlated with cracking susceptibility.

\section{Discussion}

Prior research on carrot cracking and breakage focused on water relations (Golacki,
1993; Hole et al., 1999; McGarry, 1993, 1995; Sorensen, 1997) and structural characteristics of the phloem parenchyma (Hole et al., 1999; McGarry, 1995; Sorensen and Harker, 2000). Results of this study suggested that those may not be the predominate factors governing the degree of root damage observed in commercial fields during harvesting and handling. We found a 10 -fold difference in root cracking susceptibility among commercial fields of the same cultivar, with only a minor portion of that variability attributable to root water status. McGarry $(1993,1995)$ reported that both water potential and turgor potential were negatively correlated with failure force of phloem parenchyma. Similarly, Golacki (1993) found that carrot resistance to impact loading decreased with increased moisture content (increasing water potential). However, in these studies carrots were apparently obtained from a single field source, so there were no confounding effects of production environment. In a series of experiments Hole et al. (1999) found no consistent relationship between root cracking susceptibility and water status, either within or between cultivars. Clearly, the stress induced within carrot roots by turgor potential influences root splitting (as demonstrated by the overall increase in cracking after hydration of roots from the survey fields, and the marginal decrease in cracking susceptibility observed in roots harvested at mid-day compared to early morning), but root water status explained only a minor portion of the field-to-field variability we observed.

Similarly, the strength and stiffness of phloem parenchyma tissue does not appear to be a major factor controlling susceptibility to damage during harvesting and handling. Comparing cultivars which ranged from $4 \%$ to $73 \%$ cracking incidence on an impact test, Hole etal. (1999) found that parenchyma tensile strength, fracture toughness, and residual strain were unrelated to cracking incidence. We found differences among cultivars in susceptibility to cracking and breakage, but the lack of correlation between cracking incidence and root strength and stiffness, and the profound effect of periderm removal on all of these parameters, call into question the importance of parenchyma tissue strength. Indeed, the characteris- 
Table 3. Effect of cultivar and periderm removal on root cracking susceptibility and resistance to breakage.

\begin{tabular}{|c|c|c|c|c|c|c|c|c|}
\hline \multirow[b]{2}{*}{ Year } & \multicolumn{2}{|c|}{$\begin{array}{l}\text { Percent } \\
\text { cracked }^{z}\end{array}$} & \multicolumn{2}{|c|}{$\begin{array}{l}\text { Crack } \\
\text { index }\end{array}$} & \multicolumn{2}{|c|}{$\begin{array}{l}\text { Tensile stress } \\
\text { at failure } \\
\left(\mathrm{N} \cdot \mathrm{mm}^{-2}\right)^{\mathrm{y}}\end{array}$} & \multicolumn{2}{|c|}{$\begin{array}{l}\text { Modulus of } \\
\text { elasticity } \\
\left(\mathrm{N} \cdot \mathrm{mm}^{-2}\right)^{y}\end{array}$} \\
\hline & Intact & Peeled & Intact & $\overline{\text { Peeled }}$ & Intact & Peeled & Intact & Peeled \\
\hline More Cuts & $51 \mathrm{a}$ & 1 & $0.76 \mathrm{a}$ & 0.02 & $5.05 \mathrm{a}$ & $5.58 \mathrm{abc}$ & 6.17 & $4.57 \mathrm{bc}$ \\
\hline Sugar Snax & $50 \mathrm{a}$ & 1 & $0.58 \mathrm{ab}$ & 0.01 & $3.84 \mathrm{~cd}$ & $5.22 \mathrm{bc}$ & 5.38 & $4.42 \mathrm{bc}$ \\
\hline Top Cut & $44 \mathrm{a}$ & 0 & $0.55 \mathrm{ab}$ & 0.00 & $4.19 \mathrm{bcd}$ & $6.05 \mathrm{a}$ & 5.58 & $5.37 \mathrm{a}$ \\
\hline Columbia & $43 \mathrm{a}$ & 0 & $0.65 \mathrm{ab}$ & 0.00 & $4.25 \mathrm{bc}$ & $5.13 \mathrm{c}$ & 5.78 & $4.53 \mathrm{bc}$ \\
\hline HM-02 & $35 \mathrm{a}$ & 2 & $0.41 \mathrm{~b}$ & 0.02 & $4.03 \mathrm{bcd}$ & $5.27 \mathrm{bc}$ & 5.63 & $4.29 \mathrm{c}$ \\
\hline Tasty Peel & $35 \mathrm{a}$ & 1 & $0.44 \mathrm{~b}$ & 0.01 & $4.14 \mathrm{bcd}$ & $5.58 \mathrm{abc}$ & 5.47 & $4.50 \mathrm{bc}$ \\
\hline Trinity & $14 \mathrm{~b}$ & 1 & $0.15 \mathrm{c}$ & 0.00 & $4.36 \mathrm{~b}$ & $5.34 \mathrm{bc}$ & 5.52 & $4.40 \mathrm{bc}$ \\
\hline Mean & 40 & $1^{* *}$ & 0.53 & $0.01^{* *}$ & 4.17 & $5.48^{* *}$ & 5.65 & $4.68^{* *}$ \\
\hline
\end{tabular}

${ }^{2}$ Mean of $\mathrm{N}$ treatments.

${ }^{y}$ Only grower $\mathrm{N}$ treatment tested.

${ }^{x}$ Mean separation by Duncan's multiple range test at $p<0.05$.

${ }^{* *}$ Significant differences for peeled roots vs. intact roots across cultivars at $p<0.01$.

Table 4. Correlation of root cracking susceptibility and environmental variables; data from 31 fields.

\begin{tabular}{lccc}
\hline & \multicolumn{2}{c}{ Range } & $\begin{array}{c}\text { Correlation (r) with } \\
\text { \% cracking }\end{array}$ \\
\cline { 2 - 4 } Parameter & Max & Min & 0.36 \\
Mean air temp final $30 \mathrm{~d}\left({ }^{\circ} \mathrm{C}\right)$ & 27 & 7 & 0.44 \\
Exchangeable Ca $\left(\mathrm{cmol}^{\mathrm{z}} \mathrm{kg}^{-1}\right)$ & 2.3 & 30.8 & 0.52 \\
Exchangeable $\mathrm{Mg}\left(\mathrm{cmol} \cdot \mathrm{kg}^{-1}\right)$ & 0.2 & 8.3 & -0.48 \\
Percent sand & 23 & 91 & 0.45 \\
Percent silt & 5 & 53 & 0.47 \\
Percent clay & 4 & 24 & \\
\hline
\end{tabular}

${ }^{2}$ All correlations significant at $p<0.05$.

tics of the periderm appeared to be paramount in controlling cracking and breakage. Periderm removal essentially eliminated differences in cracking among fields, cultivars, and $\mathrm{N}$ rates, increased tensile stress at breakage, and nearly doubled deformation distance before breakage. These results suggested that the periderm had less flexibility than the phloem parenchyma. When the periderm fractured, the fracture readily propagated through the parenchyma, but in the absence of the periderm the parenchyma absorbed stress, usually without fracture. Other studies also reported that the energy required to fracture peeled roots was significantly greater than that required for intact roots (Cantwell et al., 1991; Millington, 1984).

Nitrogen fertility influenced periderm strength. Excessive $\mathrm{N}$ fertilization above the level required to maximize root yield resulted in increased cracking, and crack severity, across locations and cultivars. This has important practical implications. $\mathrm{N}$ fertilization rate is often determined in part by the appearance of the leaves; during mechanical harvesting the roots are pulled from the ground by the leaves, and growers want to ensure that the leaves have sufficient strength for this purpose. The tendency to over-fertilize was demonstrated by the much higher $\mathrm{N}$ rates applied to the survey fields for which records could be obtained than were applied in the $\mathrm{N}$ trial fields. Bienz (1965) also linked heavy $\mathrm{N}$ fertilization to increased cracking, but in that study it was not clear if the increased cracking observed was due to $\mathrm{N}$ effects per se, or to the influence of $\mathrm{N}$ on root size, which affected cracking susceptibility (Cantwell et al., 1991; Hole et al., 1999). In the present study $\mathrm{N}$ fertility did not affect resistance to transverse breakage. It is possible that the form of $\mathrm{N}$ applied (urea, nitrate, ammonium) may differentially affect cracking or breakage sensitivity, but that factor was not addressed in this study.

The large differences in cracking susceptibility among the $\mathrm{N}$ trial sites, and the lack of correlation of tissue $\mathrm{N}$ status and cracking in the survey fields, suggested that other field factors are also important. Irrigation management did not appear to be a significant factor. Nortje and Henrico (1986) reported that allowing severe soil moisture depletion between irrigations increased root cracking, but in that study cracking incidence was very low $(<5 \%)$ in all treatments, and represented cracking that occurred before harvest. The positive correlation between cracking and air temperature in the final month of growth suggested that rapid root growth was associated with weaker periderm tissue. While marketing considerations make it impractical for growers to adjust planting dates to minimize cracking, the correlation of cracking with soil texture suggested that field selection may be a viable method of minimizing losses. Potential mechanisms through which soil texture could influence cracking susceptibility include aeration effects on periderm structure, and influence on the number and structure of lateral roots. Millington (1984) found that nearly $80 \%$ of carrot root fractures occurred at the site of a lateral root.

While cultivar effects on cracking have been widely reported, our results also demonstrated that cultivars deemed by the commercial industry to have characteristics suitable for the demanding cut-and-peel segment of the fresh market industry vary considerably in cracking sensitivity. Periderm strength and desirable crispness characteristics do not appear to be intrinsically linked, as 'Trinity', the least cracking-sensitive cultivar, had root strength and stiffness characteristics intermediate to the other cultivars.

In summary, carrot root cracking susceptibility is to a large extent governed by periderm strength, which in turn is affected by genetic and environmental factors. Practical methods of minimizing root cracking include cultivar selection, $\mathrm{N}$ fertility management and, perhaps, field selection based on soil texture.

\section{Literature Cited}

Bienz, D.R. 1965. Carrot splitting and second growth in central Washington as influenced by spacing, time for sidedressing, and other cultural practices. Proc. Amer. Soc. Hort. Sci. 86:406-410.

Cantwell, M., G. Morden, V. Rubatzky, and P. Chen. 1991. Tests to monitor carrot cracking and breaking susceptibility, p. 91-103. Proceedings of the EUCARPIA meeting on breeding of carrots, Avignon-Montfavet, France, 18-20 June.

Fulton, A., R. Buchner, B. Olsen, L. Schwank1, C. Gilles, N. Bertagna, J. Walton, and K. Shackel. 2001. Rapid equilibrium of leaf and stem water potential under field conditions in almonds, walnuts and prunes. HortTechnology 11:609-615.

Gee, G.W. and J.W. Bauder. 1982. Particle-size analysis. p. 383-411. In: A. Klute (ed.). Methods of soil analysis: Part 1. Physical and mineralogical methods. ASA Monogr. 9.

Golacki, K. 1993. Carrot root resistance to impact loading in relation to root moisture content and water potential. Zeszty Problemowe Postepow Nauk Rolniczych 399:83-86.

Hole, C.C., R.L.K. Drew, B.M. Smith, and D. Gray. 1999. Tissue properties and propensity for damage in carrot (Daucus carota L.) storage roots. J. Hort. Sci. Biotechnol. 74:651-657.

Kokkoras, I.F. 1995. The effect of temperature and water status of carrot tissue on residual strains and stresses. Acta Hort. 379:491-498.

McGarry,A. 1993. Influence of water status on carrot (Daucus carota L.) fracture properties. J. Hort. Sci. 68:431-437.

McGarry,A. 1995. Cellular basis of tissue toughness in carrot (Daucus carota L.) storage roots. Ann. Bot. 75:157-163.

Meyer, G.A. and P.N. Keliher. 1992. An overview of analysis by inductively coupled plasma-atomic emission spectrometry, p. 473-505. In: A Montaser and D.W. Golightly (ed.). Inductively coupled plasmas in analytical atomic spectrometry. VCH Publ. Inc. New York.

Millington, S. 1984. Quality of carrots in the United Kingdom with respect to harvester and packinghouse damage. Acta Hort. 163:127-136. 
Mohsenin, N.N. 1986. Physical properties of plant and animal materials: Structure, physical characteristics and mechanical properties. Gordon and Breach, New York.

Nelson, D.W. and L.E. Sommers. 1982. Total carbon, organic carbon and organic matter, p. 539-579. In:A.L. Page etal. (eds.) Methods of soil analysis: Part 2. Chemical and microbiological properties. ASA Monogr. 9.

Nortje, P.F. and P.J. Henrico. 1986. The influence of irrigation interval on crop performance of carrots (Daucus carota L.) during winter production.
Acta Hort. 194:153-158.

Pella, E. 1990. Elemental organic analysis: Part 2: State of the art. Amer. Lab. (Aug.):22:28-32.

Olsen, S.R. and L.E. Sommers. 1982. Phosphorus, p. 403-430. In: A.L. Page et al. (eds.). Methods of soil analysis: Part 2. Chemical and microbiological properties. ASA Monogr. 9.

Sah, R.N. and R.O. Miller. 1992. Spontaneous reaction for acid dissolution of biological tissues in closed vessels. Anal. Chem. 64:230-233.

Sorensen, L. 1997. Harvest splitting in carrot storage roots, p. 160-164. Proceedings of the
EUCARPIA Carrot Working Group, Krakow, Poland, 1-5 Sept.

Sorensen, L. and F.R. Harker. 2000. Rheological basis of splitting in carrot storage roots. J. Amer. Soc. Hort. Sci. 125:212-216.

Thomas, G.W. 1982. Exchangeable cations, p 159-165. In: A.L. Page et al. (eds.) Methods of soil analysis: Part 2. Chemical and microbiological properties. ASA Monogr. 9.

Thompson, S. J. and C. F. Armstrong. 1987. Calibration of the watermark model 200 soil moisture sensor. Appl. Eng. Agr. 3:186-189. 